\title{
THE ROLE OF ECONOMIC FREEDOM, TRADE AND TECHNOLOGY ON TOTAL FACTOR PRODUCTIVITY GROWTH
}

\author{
Cumhur TAŞ ${ }^{1}$, Veysel ULUSOY²
}

\begin{abstract}
There are many studies on Total Factor Productivity growth in the literature. These studies generally cover the pairwise correlation between total factor productivity growth and other variables. There is not multivariable study. This study examines relationship between economic freedom, human capital, intra-industry trade, foreign direct investment and their interaction effect on total factor productivity growth in natural resource rich and OECD countries. Panel data analysis is used in covering 20 Natural Resource Rich, 34 OECD countries between 1980 and 2014. Instrumental variables and Two Step Generalized Method of Moments are used to model relationship. There is a significant relation between total factor productivity growth and other variables in both models except foreign direct investment in natural resource rich countries.
\end{abstract}

Keywords: Intra Industry Trade, Foreign Direct Investment, Human Capital, Economic Freedom, Total Productivity Growth, Generalized Method of Moments (GMM).

JEL Classification: F13, F36, N30, D02, D24, C23

\section{TOPLAM FAKTÖR VERIMLILIIĞİ BÜYÜMESINDE EKONOMIKK ÖZGÜRLÜK, TICARET VE TEKNOLOJININ ROLÜ}

\begin{abstract}
$\ddot{O} z$
Literatürde Toplam Faktör Verimliliği artışı ile ilgili birçok çalışma bulunmaktadır. Bu çalışmalar genellikle toplam faktör verimliliği büyümesi ile diğer değişkenler arasındaki ikili korelasyonu kapsamaktadır. Çok değişkenli çalışma bulunmamaktadır. Bu çalışma ekonomik özgürlük, insan sermayesi, endüstri içi ticaret, doğrudan yabancı yatırım arasındaki ilişkiyi ve bunların doğal yaynak zenginliği ve OECD ülkelerinde toplam faktör verimliliği artışı üzerindeki etkilerini incelemektedir. Panel veri analizi 1980-2014 döneminde 20 doğal kaynak zengini, 34 OECD ülkesini kapsamaktadır. İlişkiyi modellemek için araç değişkenler ve iki adımlı genelleştirilmiş momentler yöntemi kullanılmıştır. Her iki modelde de doğal kaynak zengini ülkelerde doğrudan yabancı yatırım dışında toplam faktör verimliliği artı̧ı ile diğer değişkenler arasında bir ilişki olduğu görülmüştür..
\end{abstract}

Anahtar Kelimeler: Endüstri İçi Ticaret, Doğrudan Yabancı Yatırım, İnsan Sermayesi, Ekonomik Özgürlük, Toplam Faktör Verimliliği, Genelleştirilmiş Momentler Yöntemi (GMM).

JEL Sinıflandırma: F13, F36, N30, D02, D24, C23

\footnotetext{
${ }^{1}$ Dr. Yeditepe Üniversitesi, tas.cumhur@ gmail.com ORCID: 0000-0003-2583-5744

${ }^{2}$ Prof.Dr.Yeditepe Üniversitesi, vulusoy@ yeditepe.edu.tr ORCID: 0000-0001-7227-894X
} 


\section{Introduction}

The increase in the production consumption volume within an economy over the time creates economic growth. Economic growth is important for each country at every level of development. Various views on productivity and economic growth are mainly based on Neoclassical and new growth (endogenous) theories. In neo-classical view, the short-term determinant of growth is capital accumulation. As approaching the steady state equilibrium, marginal rate of return of capital will decrease and the determinant of growth will be productivity which is exogenous and expressed as technological development in long run. Neoclassical theory, despite their flexibility, does not accept that per capita national income can continuously increase in an economy. These models are deficient in explaining the source of technological development, arguing that the key source of growth is technological development in the long-run. This deficiency has been solved by endogenous growth theories considering technological development which adds production function as a variable influenced by economic units decisions. Therefore; structural parameters such as savings rate, education and expenditure on $R \& D$ (research and development), commercial and financial openness, infrastructure, competitiveness, financial development and institutional structure have effect on Total Factor Productivity (TFP) growth in long-term. Thus, the endogenous theory suggests that technological development cannot be considered independent from the factors mentioned above, and that improvements in these factors can accelerate technological development (Blanchard, 2003).

Capital deepening is generally the main determinant of TFP, so that policies that will accelerate capital accumulation affects TFP growth positively. The definition of the capital has been expanded and importance has been attached to the human capital similar as the physical capital in the endogenous growth models. So, the knowledge and skills are put forward in the theory of endogenous growth. In endogenous growth theory, physical capital positively affects human capital, so the increase in physical capital also causes an increase in human capital (HC). The link between technological development and physical and human capital is important. Also HC creates a base for technological infrastructure and R\&D work.

The main reasons for the gap in income growth and income between countries are the natural resources that the country have and the differences in capital per capita. However, their share can be smaller than expected. The main factor creating this income per capita gap among the countries is the variations in total factor productivity. TFP creates this difference by affecting labor productivity both directly and indirectly (Prescott, 1997). When the labor factor is considered as unqualified labor and educated labor, i.e. human capital, it is possible to establish relation between TFP and human capital. In Endogenous Growth Theory, human capital positively affect TFP growth.

When emerging market economies are taken into consideration, foreign direct investments (FDI) are the most important item in total private capital movements. Foreign direct investments flowing to developing countries are considered as key driver of economic development in general as well as increase in employment and national income. Benefits of direct investment vary by country and sector. The effect of direct investments on productivity is positive and stronger in developed countries and sectors with relatively high level of technology. 
In developing countries, foreign direct investment supported by appropriate policies are expected to affect growth through specific channels and development and TFP in positive ways. According to report by United Nations Conference Trade and Development (UNCTAD) (1999), direct investment has complementary effects on transfer of new technology and effective use of technology.

Gwartney et al. (2004), states that "economic freedom as a right granted to individuals; based on the laissez passer philosophy. In addition an economy to be free must reveal some qualities such as, public sector size, economic structures and markets use, monetary policy and stability of price, using alternative currencies in freedom, the existence of legal order and security of the private property, freedom of foreign trade, free exchange of capital in capital markets, freedom of enterprise, policies to protect the value of money"

Economic freedom should be measurable both for determining the role of liberties in the development of countries and for comparative analysis of the freedom levels of countries. After 1990, calculations by international institutions - Heritage Foundation and the Fraser Instituteplay an important role in making economic freedom quantitative to be measurable. After this, it can be predicted, whether or not changes in economic freedom level affect economic performance. According to these estimations made at the same time countries that are more liberal in economy than other countries seem to achieve faster growth, higher per capita income levels, lower unemployment rates, broader political and civil liberties and lower levels of corruption (Acar, 2010).

The more economic freedom the more economic growth is stated in the literature. Even when the results of these studies are examined, large number of studies reaching the conclusion that a positive and meaningful correlation between economic freedom and economic growth has been seen that is parallel to the theory, both domestic and foreign studies in the literature. However, some studies analyzing certain years and certain countries have found statistically insignificant or negative results using sub-indices of economic freedom. The reason is that, the institutional structure of developing countries has not progressed sufficiently.

The fact that the classical trade theories clarify the country and inter-country differences and that inter-industry change is accepted as the starting point of international trade is inadequate in explaining the process of globalization and new trade transactions in the 1960's. New trade theories are concentrating on firm and explaining foreign trade based on productivity differences. For this reason, a microeconomic approach is shown at the basis of the theories. Theories are developed considering Krugman's (1979) New Trade Theory, which emphasizes firm differences. This theory explains the increasing Intra-Industry Trade (IIT) and firm-based changes in the globalization process. In the model, the differences between the firms, sectors and countries explain foreign trade (Melitz, 2008).

New trade theories can be summarized as development that start with liberalization policies in foreign trade, increases welfare throughout the country by redistribution of resources to more productive firms. The microeconomic dimensions of the new trade theories are that output produced together with the increase in the sectoral production creates results considering whole economy (Melitz, 2008).

Macroeconomic aspects of new trade theories have been developed by Bernard et. al., (2006) and other studies. Wang and Xie (2008) created a new dynamic growth model to include heterogeneity and efficiency gains. 


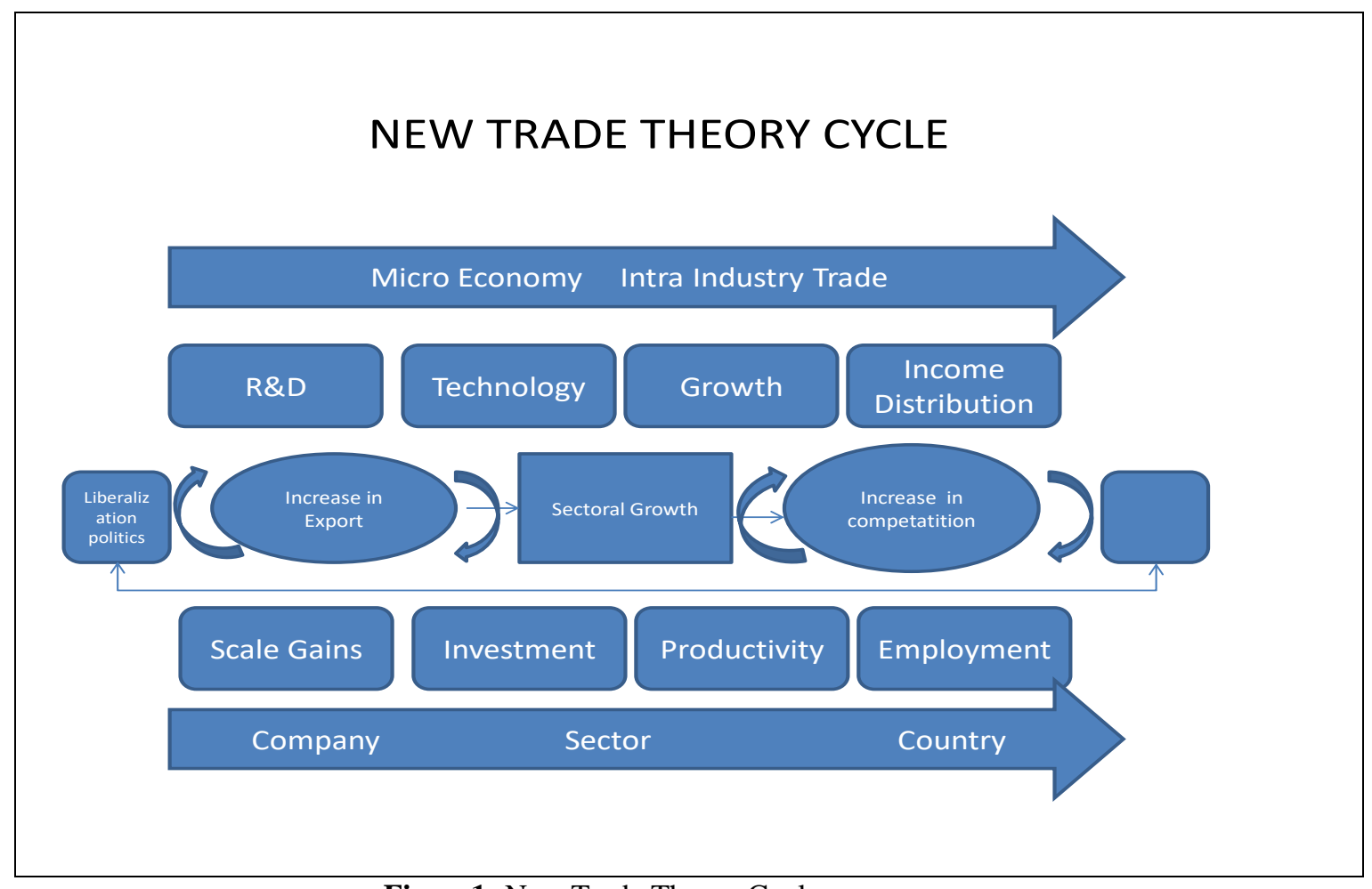

Figure1: New Trade Theory Cycle Source: Bakkalcı (2013)

Figure 1 outlines the mechanism of microeconomic process affecting macroeconomics. As a result of liberalization policies, there are developments leading to productivity differences between firms, and with the effect of resource distribution, the most productive firms are starting to be influential in the market. It is known that the most productive exporting firms integrated into the global system. Companies entering the export market want to be permanent in the market. New R\&D expenditures are made, new technologies are being developed and new investments are made. Developments of companies dealing with exports result in sectoral growth. As a result, sectoral developments reveal macro effects that have impact on the country's economy. When macro effects begin with competition, a new cycle is created that results in growth-income distribution-employment and productivity growth. The most important factor that can influence this cycle is foreign trade. As a result of these developments, the average productivity of countries making foreign trade increases. (Namini, 2007).

It is a widespread view that in natural resource rich countries (NRR Countries), natural capital supports the development of economy and increases growth performance. So far, the evidence shows that in natural resource rich countries, economic growth decelarates over the time. In many countries, natural resource richness can not be main support in the economic development. This is why it is the subject of interest of economists and although there is no agreement on, many theoretical explanations have been introduced on this subject.

This study examines relationship between economic freedom, intra-industry trade, foreign direct investment, HC and TFP growth which are the main components of the Total Factor Productivity in NRR and OECD Countries. The difference of this study from other studies is the analysis of interaction effect of the variables on TFP growth. 
This study consists of 5 sections. In the second section, international studies on economic freedom index (EFI), human capital (HC), intra-industry trade (IIT) and foreign direct investment (FDI) on TFP growth are examined in detail and presented under separate headings. Followings are; methodology, data and empirical results.

This study developes the study by Ulusoy \& Taş (2017) that examines the relationship between economic freedom and total factor productivity in oecd and nrr countries. In study, the general economic outlook of NRR countries, recource curse hypothesis and their presence in these countries are investigated. Ulusoy \& Taş (2017) discuss the link between natural resource rents, economic freedom, institutions, natural resource revenue and total factor productivity growth in above mentioned study. In this study, in addition to economic freedom index new variables are added in the model and interaction effect of these variables (i.e. IIT*EFI interaction effect estimates how the effect of intra industry trade on productivity growth depends on economic freedom) on TFP growth are analyzed.

\section{Review of literature}

The cases covering the effects of EFI, HC, IIT and FDI together on TFP growth are not observed through literature review. There are studies covering the relation between TFP and one of above variables. They examine their effects on TFP by individually.

\subsection{Foreign Direct Investment (FDI) - Total Factor Productivity Growth}

FDI has important effects on economic variables. FDI means cross-border investment by getting control or management of an enterprise in host economy. FDI positively increases economic growth by new technology transfer and spillover efficiency.

FDI and economic growth relation occurs by two channels: capital accumulation and TFP. Through capital accumulation, Foreign direct investment results in an increase in total investment of domestic economy by means of a net addition created by superior technology spilling over to domestic firms' efficiency. Although FDI has positive impact on an economy, it can also crowd-out domestic investment and reduce competition. That's why the net effect of FDI is not obvious.

FDI and TFP relation literature is given on Table 1.

Table 1: FDI and TFP Literature

\begin{tabular}{|c|c|c|c|c|}
\hline Authors & Country & Period & Method & Results \\
\hline $\begin{array}{l}\text { Azman-Saini et } \\
\text { al. (2010) }\end{array}$ & 85 Country & $\begin{array}{l}1975- \\
2005\end{array}$ & GMM System & $\begin{array}{l}\text { No direct relation } \\
\text { between FDI- } \\
\text { TFP/economic } \\
\text { freedom }\end{array}$ \\
\hline $\begin{array}{l}\text { Alfaro et al. } \\
(2009)\end{array}$ & 62 Country & $\begin{array}{l}1975- \\
1995\end{array}$ & $\begin{array}{l}\text { Cross-country } \\
\text { OLS } \\
\text { regressions }\end{array}$ & $\begin{array}{l}\text { No direct relation } \\
\text { between } \\
\text { TFP/well developed } \\
\text { financial market }\end{array}$ \\
\hline $\begin{array}{l}\text { Baltabaev B. } \\
(2014)\end{array}$ & $\begin{array}{l}49 \text { Country ( } 21 \\
\text { Developed, } 28 \\
\text { developing } \\
\text { countries } \\
\text { including } \\
\text { transition } \\
\text { economics) }\end{array}$ & $\begin{array}{l}1974- \\
2008\end{array}$ & $\begin{array}{l}\text { Dynamic } \\
\text { panel GMM }\end{array}$ & $\begin{array}{l}\text { Positive effect on TFP } \\
\text { growth }\end{array}$ \\
\hline
\end{tabular}




\begin{tabular}{|c|c|c|c|c|}
\hline$\underline{\text { Authors }}$ & $\underline{\text { Country }}$ & Period & $\underline{\text { Method }}$ & $\underline{\text { Results }}$ \\
\hline Woo J. (2009) & $\begin{array}{l}92 \text { Country (22 } \\
\text { Developed, } 70 \\
\text { Developing } \\
\text { Countries) }\end{array}$ & $\begin{array}{l}1970- \\
2000\end{array}$ & $\begin{array}{l}\text { OLS and } \\
\text { fixed-effect } \\
\text { panel } \\
\text { regressions }\end{array}$ & $\begin{array}{l}\text { FDI has positive } \\
\text { effect on TFP growth. }\end{array}$ \\
\hline $\begin{array}{l}\text { De Mello L.R. } \\
\text { (1999) }\end{array}$ & 33 Country & $\begin{array}{l}1970- \\
1990\end{array}$ & $\begin{array}{l}\text { Panel data } \\
\text { analysis }\end{array}$ & $\begin{array}{l}\text { Significant in } \\
\text { developed countries. } \\
\text { Not in developing } \\
\text { countries (minus } \\
\text { sign) }\end{array}$ \\
\hline $\begin{array}{l}\text { Wang \& Wong } \\
\text { (2009) }\end{array}$ & $\begin{array}{l}69 \text { Countries } \\
\text { (Developing) }\end{array}$ & $\begin{array}{l}1970- \\
1989\end{array}$ & $\begin{array}{l}\text { Panel } \\
\text { regressions } \\
(\mathrm{SUR})\end{array}$ & $\begin{array}{l}\text { No direct relation } \\
\text { between FDI-TFP }\end{array}$ \\
\hline $\begin{array}{l}\text { Borensztein et al. } \\
\text { (1998) }\end{array}$ & $\begin{array}{l}69 \text { Developing } \\
\text { Countries }\end{array}$ & $\begin{array}{l}1970- \\
1989\end{array}$ & $\begin{array}{l}\text { SUR } \\
\text { (Seemingly } \\
\text { Unrelated } \\
\text { Regressions) }\end{array}$ & $\begin{array}{l}\text { No direct relation } \\
\text { between FDI-TFP }\end{array}$ \\
\hline $\begin{array}{l}\text { Herzer\& } \\
\text { Donaubauer,J. } \\
(2018) \text {. }\end{array}$ & $\begin{array}{l}49 \text { developing } \\
\text { countries }\end{array}$ & $\begin{array}{l}1981- \\
2011\end{array}$ & $\begin{array}{l}\text { Panel } \\
\text { Cointegration, } \\
\text { Causality }\end{array}$ & $\begin{array}{l}\text { Negative effect of FDI } \\
\text { on TFP growth in } \\
\text { developing countries. }\end{array}$ \\
\hline
\end{tabular}

Source: Author

Conflicting results in empirical studies have been observed although net FDI creates benefits to the host country in theoretical literature. FDI increases growth on the host countries (De Mello, (1999), Woo, (2009), Baltabaev, (2013)). However, there are some studies demonstrating no relation or negative relation between FDI and TFP (Irandoust and Ericsson (2001), Görg and Greenaway, (2004), Alfaro et al., (2009), Wang\&Wong (2009), Azman Saini et al. (2010)). These studies confirm effect of FDI on TFP growth in developed countries. However it is hard to observe positive results in developing countries.

The effect of natural resources on FDI in terms of positive and negative impact is still in dispute. "Countries that rely heavily on extractive industries have seen large increases in natural resource rents, but their growth will not be sustainable unless they invest in productive assets, including human capital" (Bopkin et al.,2015).

Recent studies indicate that resource-poor countries have more FDI than some resourceabundant ones (Poelhekke \&Van der Ploeg, 2013; Asiedu,2013). Moreover, there are capital inflows to especially gold, diamonds, oil, gas sectors in resource rich countries. However, unbalanced development may take place due to capital flows in the host countries. This may not constitute positive spill-over of FDI.

Bengoa and Sanchez-Robles (2003), study the effect of FDI and EFI on economic growth. They use panel data analysis covering 18 countries data in the period 1970-1999 and find that the volume of foreign direct investments increases as paralell to economic freedom expansion. Also this leads to rapid economic growth consequently.

Naanwaab and Diarrassouba (2016), disscuss the effects of economic freedom on FDI in high and middle income countries. They observe positive and significant relation between EFI and FDI. Also it is observed that HC is an important determinant of FDI in all countries.

Akkaya (2019) analysis the relationship between direct foreign investment, economic freedom and economic growth in the 12 emerging market countries in the period of 1995-2016 by using dynamic panel data method. 
According to the results of the analysis, there is a positive relation between FDI and economic growth. Also no relation with economic freedom has been observed. Moreover, high technological product exports and population affect FDI. There is no relation between FDI and trade openness, interest rates, unemployment rate and.domestic consumption.

\subsection{Human Capital (HC) and Total Factor Productivity Growth (TFP)}

Schultz (1961) mentions that; "I shall concentrate on five major categories of Human Capital : (1) Health facilities and services, broadly conceived to include all expenditures that affect the life expectancy, strength and stamina, and the vigor and vitality of people (2) On-the-job training, including old-style apprenticeship organized by firms (3) Formally organized education at the elementary, secondary, and higher levels (4) Study programs for adults that are not organized by firms, including extension programs notably in agriculture (5) Migration of individuals and families to adjust to changing job opportunities."

Lamfli (2010), proposes that HC increases productivity by enhancing average labor productivity and enriches the innovation capacity resulting in technological progress. Many economic theories suggest that $\mathrm{HC}$ has significant role on the total factor productivity growth (Nelson \& Phelps, 1966; Romer, 1990a, 1990b; Aghion \& Howitt, 1998). They also argue that this role takes place by facilitating technology spillover and accelerating domestic technological innovations.

Fleisher \&Chen, (1996), Acemoglu et al., (2006), Vandenbussche et al., (2006), Fleisher et al., (2010), discuss HC effects on technological improvements. They conclude that the composition of labor determines the type of technological improvements: innovation or imitation. Skilled labor is driving force in innovation however unskilled labor results in imitation.

Emprical results related with human capital are mixed. Human capital is important for relatively rich countries. However it has negative impact for the relatively poor countries. Human capital literature is given at Table 2

Table 2: $\mathrm{HC}$ and TFP Literature

\begin{tabular}{|c|c|c|c|c|}
\hline Authors & Country & Period & Method & Results \\
\hline $\begin{array}{l}\text { Barro, R. J. } \\
\text { (1991) }\end{array}$ & 98 & $1960 / 1985$ & & $\begin{array}{l}\text { GDP growth rate is } \\
\text { positively related to initial } \\
\text { HC }\end{array}$ \\
\hline $\begin{array}{l}\text { Romer, P.M. } \\
\text { (1990) }\end{array}$ & 112 & $1960 / 1985$ & $\begin{array}{l}\text { Least Square } \\
\text { Regression }\end{array}$ & $\begin{array}{l}\text { Initial literacy level effects } \\
\text { indirectly the rate of growth }\end{array}$ \\
\hline $\begin{array}{l}\text { Benhabib and } \\
\text { Spiegel (1994) }\end{array}$ & 78 & $1965 / 1985$ & & $\begin{array}{l}\text { HC stock level determines } \\
\text { the growth rate of TFP }\end{array}$ \\
\hline $\begin{array}{l}\text { Nelson and } \\
\text { Phelps } \\
\text { (1966) }\end{array}$ & & & & Theoritically \\
\hline $\begin{array}{l}\text { Manuelli and } \\
\text { Seshadri (2005) }\end{array}$ & & & & Theoritically \\
\hline $\begin{array}{l}\text { Miller and } \\
\text { Upadhyay } \\
\text { (2000) }\end{array}$ & 83 & $1960 / 1989$ & $\begin{array}{l}\text { Fixed effect } \\
\text { Panel }\end{array}$ & $\begin{array}{l}\text { Positive effect of } \mathrm{HC} \text { on } \\
\text { TFP. Human capital with } \\
\text { openness creates a positive } \\
\text { effect in poor countries, }\end{array}$ \\
\hline
\end{tabular}




\begin{tabular}{|c|c|c|c|c|}
\hline Authors & Country & Period & Method & $\underline{\text { Results }}$ \\
\hline $\begin{array}{l}\text { Aghion, Meghir, } \\
\text { Vandenbussche } \\
(2005)\end{array}$ & $\begin{array}{l}19 \text { OECD } \\
\text { countries }\end{array}$ & $1960 / 2000$ & Panel & $\begin{array}{l}\text { Stronger growth-enhancing } \\
\text { effect of skilled Hc on } \\
\text { economies closer to the } \\
\text { technological frontier }\end{array}$ \\
\hline $\begin{array}{l}\text { Loesler, Mies, } \\
\text { Tapia (2015) }\end{array}$ & USA & $1915 / 1939$ & $\begin{array}{l}\text { Two-stage } \\
\text { least squared } \\
\text { regressions }\end{array}$ & $\begin{array}{l}\text { Tertiary education's effects } \\
\text { on R\&D per worker or TFP } \\
\text { growth. }\end{array}$ \\
\hline $\begin{array}{l}\text { Maria J. Freire } \\
\text { Seren (2001) }\end{array}$ & $\begin{array}{l}72 \text { (non-oil } \\
\text { country), } \\
65 \text { (inter) } \\
\text { and } 22 \\
\text { (OECD) } \\
\text { countries }\end{array}$ & $1960 / 1990$ & & $\begin{array}{l}\text { Income level affects } \\
\text { positively and significantly } \\
\text { the process of human capital } \\
\text { accumulation }\end{array}$ \\
\hline
\end{tabular}

Source: Author

\subsection{Intra Industry Trade (ITT) and Total Factor Productivity Growth} (TFP)

Ricardo's "Comparative Advantage Assumption "as the essence of classical foreign trade theories, is inadequate in explaining today's world international trade. So economists sought a new theory and a new model. These models are called "New Trade Theories". However, these models are not sufficient to explain world trade in multidimensional and complex structures alone. As increasing trade between countries whose factor endowment is close to each other can not be explained by Classical International Trade Theory, so Intra Industry Trade (IIT) approach has been developed.

IIT is a foreign trade style based on simultaneous export and import of goods that enter the same industry group but show some differences in terms of appearance, quality, usage characteristics and brand. Verdoorn (1960), is first to study on IIT. Grubel \& Lloyd (1975), develop an index to measure IIT defining as "the simultaneous export and import of products in the same product categories” (Shahbaz and Lean, 2012).

Both import and export of goods at the same industrial level among countries of similar development level is defined as "Intra-Industry Trade" by Balassa (1979), Grubel and Lloyd (1975), as "Two-Way Trade" by Gray (1976), as "Trade Expansion" by Finger (1975), as "Cross (Pull) Transport" by Brander (1981), and as "Two-Way Trade in Similar Products" by Abd-El Rahman (1991). IIT usually depends on "scale economies" and "goods differentiation". However, some of the IIT's are not related to product differentiation but are made on homogeneous goods.

Countries get benefit from larger markets by means of IIT. While the product variety by a developing country on the one hand is decreasing, on the other hand the domestic consumers are able to consume more goods in a variety of ways. By producing fewer goods, countries can produce more efficiently, at lower cost, on a larger scale, and consumers have more product options. Intra-Industry Trade and TFP relation literature is given at Table 3. 
Table 3: IIT and TFP Literature

\begin{tabular}{|c|c|c|c|c|}
\hline Authors & Country & Period & Method & Results \\
\hline $\begin{array}{l}\text { Grubel, Herbert G. } \\
\text { \& Peter J. Lloyd } \\
(1975)\end{array}$ & $\overline{\mathrm{EU}}$ & $\begin{array}{l}1959- \\
1967\end{array}$ & & $\begin{array}{l}\text { The trade is mostly } \\
\text { among countries with } \\
\text { different factor } \\
\text { endowments. }\end{array}$ \\
\hline $\begin{array}{l}\text { Loertscher,R. \& } \\
\text { Wolter,F. (1980) }\end{array}$ & $\begin{array}{l}\text { OECD } \\
\text { countries }\end{array}$ & 1972 & & $\begin{array}{l}\text { Countries where market } \\
\text { size is big barrier to trade } \\
\text { is low, market entry is } \\
\text { easy, transaction cost is } \\
\text { low and development } \\
\text { level is high, there is } \\
\text { intense intra-industry } \\
\text { trade. }\end{array}$ \\
\hline $\begin{array}{l}\text { Helpman and } \\
\text { Krugman (1985) }\end{array}$ & & & & $\begin{array}{l}\text { When countries become } \\
\text { more similar in their level } \\
\text { of development, more } \\
\text { HIIT is conducted } \\
\text { between them. }\end{array}$ \\
\hline Balassa, B. (1986) & $\begin{array}{l}38 \text { country } \\
\text { (developed and } \\
\text { developing ) }\end{array}$ & 1979 & & $\begin{array}{l}\text { Economic development } \\
\text { level (GNP), domestic } \\
\text { market size, openness in } \\
\text { economy mainly increase } \\
\text { intra-industry trade. }\end{array}$ \\
\hline $\begin{array}{l}\text { Falvey and } \\
\text { Kierzkowski } \\
(1987)\end{array}$ & & & & $\begin{array}{l}\text { Factor endowment } \\
\text { differences between } \\
\text { countries results in } \\
\text { Vertical intra-industry } \\
\text { trade (VIIT) }\end{array}$ \\
\hline $\begin{array}{l}\text { Dalia Haakura \& } \\
\text { Florence Jaumette } \\
\text { (1999) }\end{array}$ & 87 & $\begin{array}{c}1970- \\
1993\end{array}$ & & $\begin{array}{l}\text { Technology diffusion is } \\
\text { easy in IIT and TFP } \\
\text { growth is more in less } \\
\text { developed countries if } \\
\text { they trade with developed } \\
\text { countries. }\end{array}$ \\
\hline Faundez S. (2011) & 28 & $\begin{array}{l}1990- \\
2008\end{array}$ & GMM & $\begin{array}{l}\text { Development in IIT } \\
\text { increases labor } \\
\text { productivity growth in } \\
\text { natural resources } \\
\text { industries. }\end{array}$ \\
\hline $\begin{array}{l}\text { Cabral,R.\& } \\
\text { Mollick, A.V. } \\
(2011)\end{array}$ & Mexico & $\begin{array}{l}1984- \\
2000\end{array}$ & $\begin{array}{l}\text { Panel } \\
\text { Data }\end{array}$ & $\begin{array}{l}\text { After entering NAFTA, } \\
\text { IIT imports had positive } \\
\text { effect on productivity and } \\
\text { this effect mainly seen in } \\
\text { labor intensive industries. }\end{array}$ \\
\hline $\begin{array}{l}\text { Lewrick, Mohler, } \\
\text { Weder (2014) }\end{array}$ & Swiss & $\begin{array}{l}1997- \\
2009\end{array}$ & & $\begin{array}{l}\text { In swiss manufacturing, } \\
\text { main factor in total TFP } \\
\text { growth is IIT allocation. }\end{array}$ \\
\hline $\begin{array}{l}\text { Rasekhi S. and } \\
\text { Ramezani M. } \\
\text { (2017) }\end{array}$ & $\begin{array}{l}50 \text { Developed and } \\
\text { Developing } \\
\text { Country }\end{array}$ & $\begin{array}{l}2001- \\
2014\end{array}$ & PVAR & $\begin{array}{l}\text { They find a positive } \\
\text { relationship between } \\
\text { economic growth and } \\
\text { intra-industry trade in the } \\
\text { developed countries and } \\
\text { negative in developing } \\
\text { countries. }\end{array}$ \\
\hline
\end{tabular}




\subsection{Economic Freedom (EF) and Total Factor Productivity Growth (TFP)}

Economic freedom is old concept in literature. Since Adam Smith, economists believe that resource supply and choice, competition in the economy, freedom to protect trade and property rights are the result of economic development. After Smith, Ricardo defenses free trade, which is a component of economic freedom. According to the classical liberal view, "economic freedom" means the absence of pressure or force in the realization of economic activities. Economic freedom allows individuals to engage freely in economic activities. Values possessed from these activities can be used freely without any external intrusions.

Economic Freedom Index provides a way to quantify economic freedom. Scully \& Slottje (1991), developed academic measure of economic freedom. Two key economic freedom indice published by the Heritage Foundation and the Fraser Institute. These two institutions regularly update their indice.

The Heritage Foundation, a research firm based in Washington, has published "Economic Freedom Index" together with Wall Street Journal since 1994. According to Heritage Report (2008), if the individual has the freedom to produce, consume, work and invest in the place where he/she wants, and if this freedom is protected and not restricted by the state, then "that country is a free country in economy".

Fraser Institute is an important institution working on the concept and defines it as, "the individual who carry out economic activities without government intervention freely"3.

Economic freedom and TFP relation literature is given at Table 4 and details of Economic freedom and sub-indices also in Appendix C.

Table 4: EFI and TFP Literature

\begin{tabular}{|c|c|c|c|c|}
\hline Authors & Country & Period & Method & Results \\
\hline $\begin{array}{l}\text { Mehlum et al. } \\
\text { (2006) }\end{array}$ & 87 & 1965-1990 & OLS & $\begin{array}{l}\text { In resource rich economies where } \\
\text { property rights is weak, } \\
\text { entrepreneurs are diverted from } \\
\text { productive to unproductive activities. }\end{array}$ \\
\hline $\begin{array}{l}\text { Arezki et al. } \\
(2011)\end{array}$ & 129 & $1970-2007$ & OLS & $\begin{array}{l}\text { Quality of political institutions } \\
\text { moderates economic growth and } \\
\text { macroeconomic stability. }\end{array}$ \\
\hline $\begin{array}{l}\text { Gwartney \& } \\
\text { Lawson, } \\
\text { (2004). }\end{array}$ & 99 & $1980-2000$ & OLS & $\begin{array}{l}\text { The results of unsound monetary } \\
\text { policies in an economy are the price } \\
\text { level volatility, economic } \\
\text { uncertainity, less investment by the } \\
\text { entrepreneurs, produvtivity decrease } \\
\text { and growth hindrence. }\end{array}$ \\
\hline $\begin{array}{l}\text { Ventura, J. } \\
\text { (1997) }\end{array}$ & & & & Theoritical \\
\hline $\begin{array}{l}\text { Cagetti \& De } \\
\text { Nardi (2006) }\end{array}$ & & & & Theoritical \\
\hline Limi (2006) & Botswana & 1999-2002 & OLS & $\begin{array}{l}\text { Regulations on business, labor and } \\
\text { credits decrease rent-seeking } \\
\text { activities resulting in transfering the } \\
\text { recource curse. }\end{array}$ \\
\hline
\end{tabular}

\footnotetext{
${ }^{3}$ https://www.fraserinstitute.org/economic-freedom/economic-freedom-basics
} 


\begin{tabular}{lclll}
\hline Authors & Country & Period & Method & Results \\
\hline $\begin{array}{l}\text { Campbell and } \\
\text { Snyder (2012) }\end{array}$ & 109 & $1990-2005$ & OLS & $\begin{array}{l}\text { A negative relation between } \\
\text { economic freedom and } \\
\text { macroeconomic volatilty . }\end{array}$ \\
\hline
\end{tabular}

Source: Author

\section{Empirical framework}

Panel regression model for natural resource rich Countries (NRR) is;

$T f p_{i, t}=\beta_{0}+\beta_{1} E f i_{i, t}+\beta_{2} I t t_{i, t}+\beta_{3} F d i_{i, t}+\beta_{4} H c_{i, t}+\pi_{i}+\rho_{i}+\varepsilon_{i, t}$

Panel regression model for The Organisation for Economic Co-operation and Development (OECD) Countries is;

$d\left(T f p_{i, t)}\right)=\beta_{0}+d\left(T f p_{i, t-1}\right)+d\left(T f p_{i, t-2}\right)+\beta_{1} d\left(E f i_{i, t}\right)+\beta_{2} I t t_{i, t}+\beta_{3} F d i_{i, t}+$ $\beta_{4} d\left(H c_{i, t}\right)+\pi_{i}+\rho_{i}+\varepsilon_{i, t}$

In Equation (1\&2), the subscripts ' $i$ ' and ' $t$ ' shows country and time respectively. $E f i_{i, t}$ indicates freedom index (EFI) (Appendix C), $T f p_{i, t}$ indicates (TFP) growth (Appendix B), $I t t_{i, t}$ indicates intra industry trade (Appendix B), $F d i_{i, t}$ indicates foreign direct investment, $H c_{i, t}$ indicates human capital (Appendix B), $\pi_{i}$ indicates country specific fixed effects, $\rho_{i}$ indicates a time dummy and $\varepsilon_{i, t}$ indicates the random error term.

The models in equations is estimated by using 20 natural resource rich countries and 34 OECD countries between the period 1980-2014. The countries are listed Appendix A.

\section{Methodology and data}

\subsection{Methodology}

Panel data analysis is appropriate methodology to examine the relation between economic freedom, intra-industry trade, foreign direct investment, human capital and total factor productivity growth in natural resource rich and OECD countries.

Panel data analysis resulting from the combination of cross-sectional data and time series plays an important role in obtaining relationships that are difficult to identify with a particular crosssection or time series. Panel data analysis is an useful method because it has more degree of freedom than time series analysis and moreover it has more observations as well as eliminating the problem of multiple linear connections to a large extent.

Some assumptions should be tested before beginning panel data analysis. First assumption is cross-sectional dependency. Pesaran (2004) $C D_{L M}$ test is applicable when ( $\mathrm{T}>\mathrm{N}$ or $\mathrm{N}>\mathrm{T}$.). Breusch-Pagan (1980) $C D_{L M 1}$ test is usable when $\mathrm{T}>\mathrm{N}$. If $\mathrm{T}=\mathrm{N}$, it is better to use Pesaran (2004) $C D_{L M 2}$ and Pesaran, Ullah and Yamagata (2008) $C D_{L M A D J}$ tests.

It is better to apply first generation unit root test in the absence of cross-sectional dependency in the series. Mainly those are, Levin, Lin and Chu, Fisher and Breitung methodology. If series includes cross-sectional dependency, second generation unit root test must be used. Some of them are; MADF (Multivariate Augmented Dickey-Fuller) SURADF (Seemingly Unrelated Regression Augmented Dickey-Fuller) and PANKPSS (Lluis Carrion-i-Silvestre et al., 2005). 
In the NRR data, Pesaran (2004) is used to test cross-sectional dependency. In the series, the cross-sectional dependency could not be seen. So, first generation unit root test is performed. No unit root is seen at level value of the variables. So the model is set up by the level values of variables. First, the model is tested for a fixed effect or a random effect and a fixed effect was seen. Heteroskedasticity and autocorrelation tests showed autocorrelation and no constant variance (heteroskedasticity) in series. Then, endogeneity test is performed. As a result of the test, it is found that only fdi is endogenous and other variables are exogenous. Since $\mathrm{T}$ is greater than N, Dynamic Generalized Method of Moments (GMM) is not appropriate for analysis. And also due to heteroskedasticity, autocorrelation and endogeneity problem, instrument variables (IV) are used in the model.

A similar process is run for the OECD countries, and a cross-sectional dependency is observed in data. So second generation unit root test is used. It is seen that by taking the first difference value of TFP and EFI, and second differences of $\mathrm{HC}$, the variables become stationary. Model tested for Fixed or Random effect. It is seen that the fixed effect occurs in the model. After testing heteroskedasticity and autocorrelation by Baltagi\&Li\&Q. (1995), variance and autocorrelation problems take place. According to the results of endogeneity tests, EFI, FDI is endogenous and HC, ITT are exogenous. Due to T is equal to N, a static two stage systematic GMM methodology is applicable, which takes into account endogeneity, heteroskedasticity and autocorrelation.

Anderson and Hsiao (1981) propose a method by which individual influences can be removed by way of the first difference transformation. In this way, it has become easier to deal with the relationship between explanatory variables and error. They take the first difference of the model and then calculate $\Delta y_{i, t-2}=\left(y_{i, t-2}-y_{i, t-3}\right)$ or $y_{i, t-2}$ as instrument variables of $\Delta y_{i, t-1}=$ $\left(y_{i, t-1}-y_{i, t-2}\right)$

The GMM approach used in the prediction of dynamic panel data models has two basic specification tests. The first is the test of second-order autocorrelation Arellano and Bond (1991) in the residual values. Second order serial correlation is not desired $(p>0.05)$ because it indicates that the equation has autocorrelation and that the proposed instrument variable is invalid. The second is the Sargan Test. Null hypothesis is that all instruments are exogenous. Mileva (2007) states that the higher the p-value, the better Sargan statistic.

\subsection{Data}

"Penn World Table publishes annually Total Factor Productivity Growth (TFP) data. Summers and Heston constructed Penn World Tables (PWT) together with the late Kravis. The PWT are explanatory source for real national accounts data. PWT database provides information on relative levels of income, output, inputs and productivity, and it covers 182 countries for the period between 1950 and 2014"4.

The study covers 34 OECD countries and 1083 observations, 20 Natural Resource Rich countries 700 observations between 1980 and 2014. The data are on annual basis. World Development Indicators online database provides the data of FDI, net inflows (\% of GDP), Freedom Index (EFI) values are between 0-10. 0 shows "less free" and 10 shows "more free".

\footnotetext{
${ }^{4}$ https://www.rug.nl/ggdc/productivity/pwt/
} 
IIT values (The Grubel-Lloyd Index) was created for each country on a country-by-country basis, taking into account the SITC (2 LEVEL) on the World Integrated Trade Society database.

Panel data is analyzed with STATA 14. Natural regression (two-stage least square) $(\mathrm{T}>\mathrm{N})$ is used in natural resource rich countries and two system static GMM model $(\mathrm{T}=\mathrm{N})$ is appropriate for OECD countries.

In natural resource rich countries, Total Factor Productivity growth has positive correlation with EFI, IIT, HC and FDI. However, in OECD countries, TFP growth has positive correlation with EFI and FDI but negative correlation with IIT, HC. Table 5-6 present descriptive statistics about variables.

Table 5: Natural Resource Rich Countries - Descriptive Statistics

\begin{tabular}{|c|c|c|c|c|c|}
\hline Variables & Observation & Mean & Std. Deviation & Minimum & Maximum \\
\hline $\mathrm{tfp}$ & 680 & 0.96 & 0.16 & 0.45 & 1.56 \\
\hline efi & 368 & 6.67 & 1.10 & 2.47 & 8.65 \\
\hline iit & 631 & 0.49 & 0.21 & & 0.86 \\
\hline hc & 680 & 2.55 & 0.60 & 1.29 & 3.72 \\
\hline fdi & 672 & 2.44 & 2.62 & 3.62 & 17.42 \\
\hline
\end{tabular}

Source: Author

Table 6: OECD Countries - Descriptive Statistics

\begin{tabular}{|c|c|c|c|c|c|}
\hline Variables & Observation & Mean & Std. Deviation & Minimum & Maximum \\
\hline $\mathrm{tfp}$ & 1150 & 0.95 & 0.12 & 0.56 & 1.54 \\
\hline efi & 633 & 7.34 & 0.81 & 3.51 & 8.84 \\
\hline iit & 1083 & 0.70 & 0.17 & 0.00 & 0.95 \\
\hline hc & 1150 & 3.01 & 0.44 & 1.47 & 3.73 \\
\hline fdi & 1065 & 3.55 & 10.50 & 58.98 & 253.49 \\
\hline
\end{tabular}

Source: Author

Table 1: The Pairwise Correlation Matrix For Natural Resource Rich and OECD Countries

\begin{tabular}{lrrrrr}
\hline & tfp & efi & iit & hc & fdi \\
\hline tfp & 1.00 & & & & \\
& $(1.00)$ & & & & \\
efi & 0.05 & 1.00 & & \\
& $(0.27)$ & & & & \\
iit & 0.18 & 0.29 & 1.00 & & \\
& $(-0.05)$ & $(-0.06)$ & & & \\
hc & 0.11 & 0.64 & 0.23 & 1.00 & \\
& $(-0.09)$ & $(0.54)$ & $(0.15)$ & & \\
fdi & 0.16 & 0.36 & 0.07 & 0.29 & 1.00 \\
& $(0.09)$ & $(0.09)$ & $(0.05)$ & $(0.08)$ & \\
\hline
\end{tabular}

Source: Author (The numbers in parentheses are for OECD countries).

\section{Empirical results}

The average value of TFP growth and the average value of other variables in OECD countries are shown in Figure 2. 


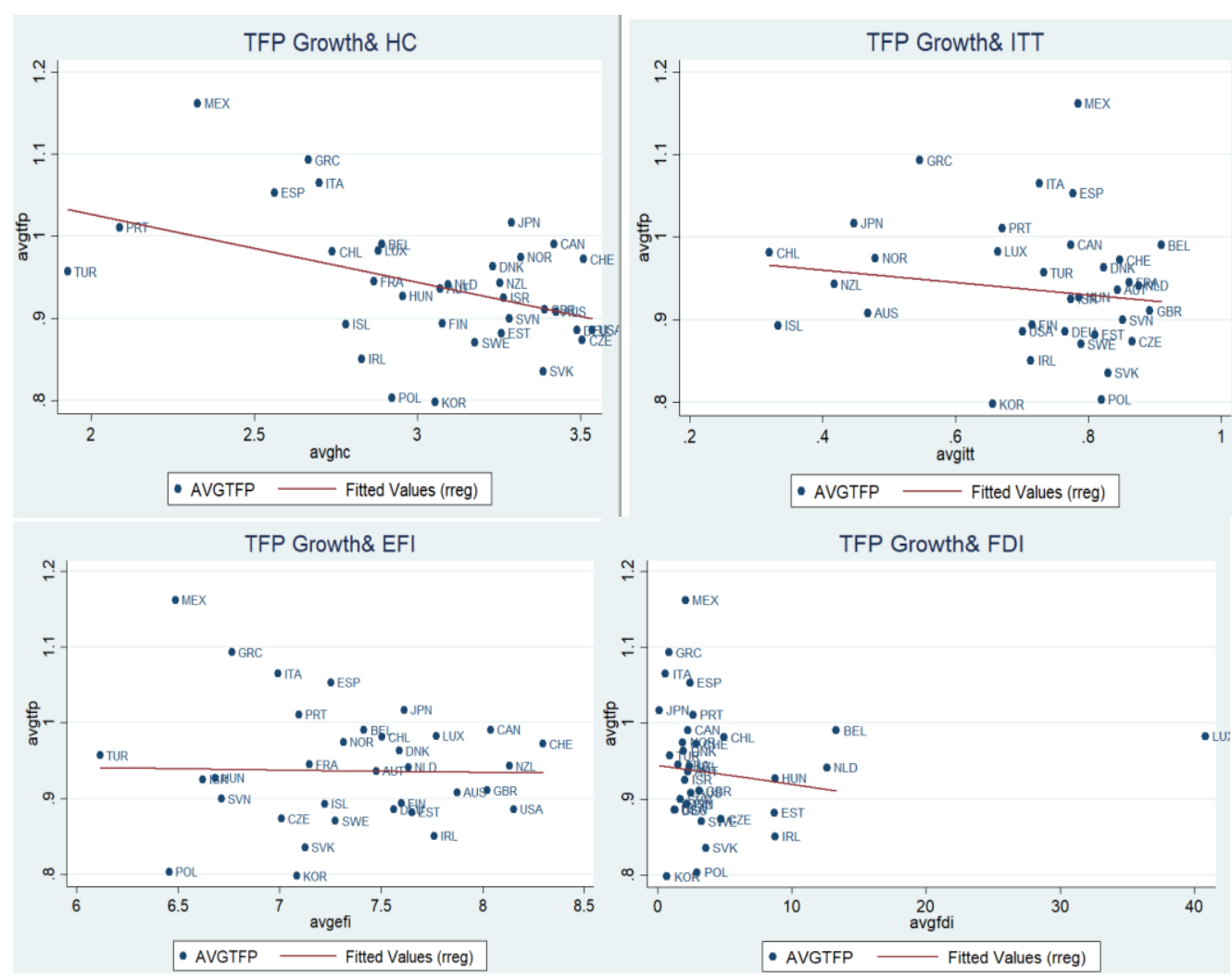

Figure 2: Average Intra-Industry Trade Versus Average Total Factor Productivity Growth (1980-2014) In OECD Countries

\section{Source:Author}

Figure 3 shows the average value of TFP growth and the average value of the other variables in natural resource rich countries
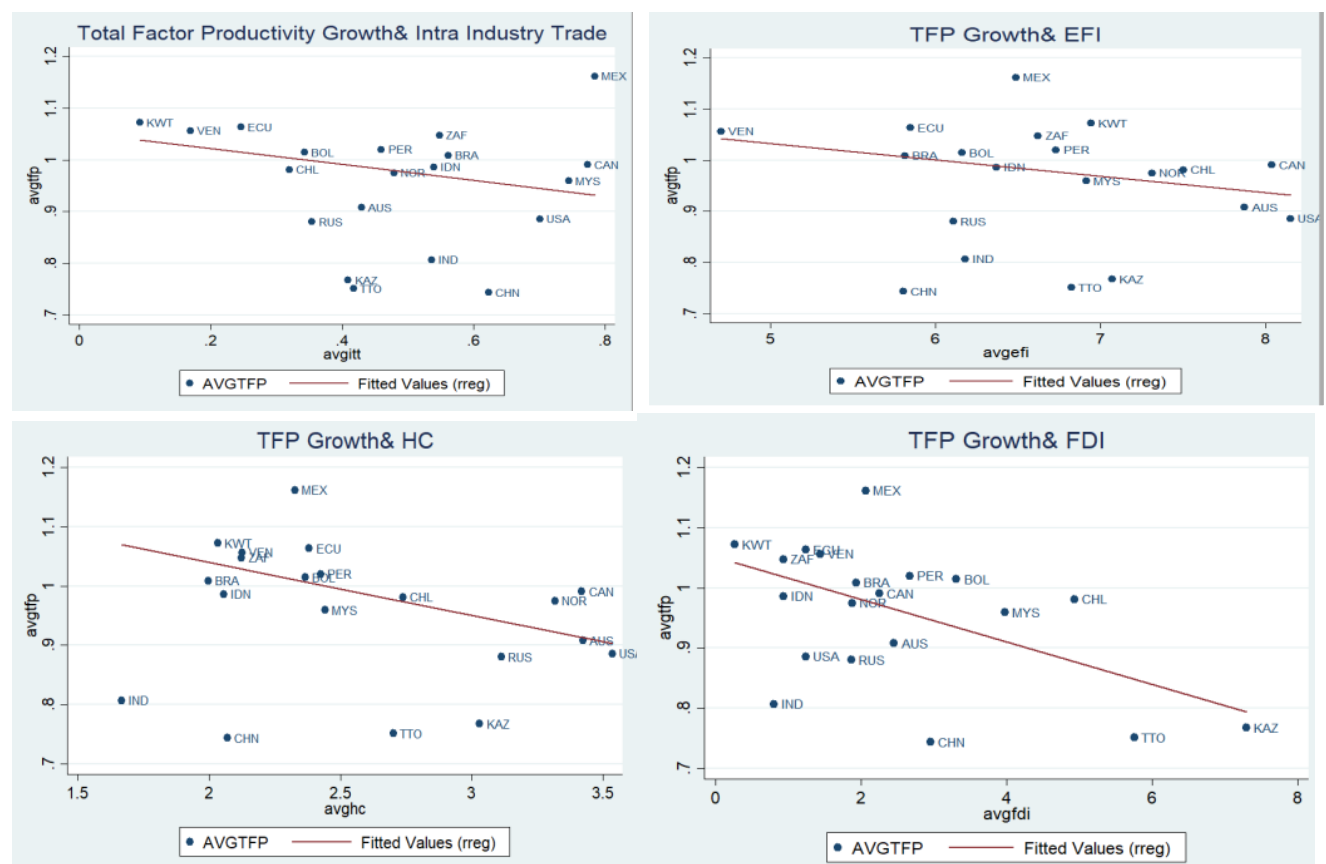

Figure 3: Average Intra-Industry Trade Versus Average Total Factor Productivity Growth (1980-2014) In Natural Resource Rich Countries 
Panel Data results including economic freedom, intra-industry trade, human capital and foreign direct investment in NRR and OECD Countries are given in Table $8 \& 9$.

Table 8: Economic Freedom, IIT, HC and FDI and TFP Growth: 19802014 in Natural Resource Rich Countries

\begin{tabular}{lccr}
\hline Variables & Coefficient & T Statistic & Probabilty \\
\hline Efi $_{\mathrm{i}, \mathrm{t}}$ & 0.0364 & 2.96 & 0.00 \\
$\mathrm{Iit}_{\mathrm{i}, \mathrm{t}}$ & -0.3856 & -5.62 & 0.00 \\
$\mathrm{Hc}_{\mathrm{i}, \mathrm{t}}$ & 0.0654 & 2.30 & 0.02 \\
$\mathrm{Fdi}_{\mathrm{i}, \mathrm{t}}$ & 0.0010 & 0.13 & 0.89 \\
Constant & 0.7374 & 7.98 & 0.00 \\
\hline
\end{tabular}

Source:Author

Table 9: Economic Freedom, IIT, HC and FDI and TFP Growth: 19802014 in OECD Countries

\begin{tabular}{lllr}
\hline Variables & Coefficient & T Statistic & Probabilty \\
\hline d. $\mathrm{Tfp}_{\mathrm{i}, \mathrm{t}-1}$ & 0.1405 & 14.03 & 0.00 \\
$\mathrm{~d} . \mathrm{Tfp}_{\mathrm{i}, \mathrm{t}-2}$ & -0.1092 & -12.70 & 0.00 \\
$\mathrm{~d} . \mathrm{Ef}_{\mathrm{i}, \mathrm{t}}$ & 0.0267 & 11.59 & 0.00 \\
$\mathrm{Iit}_{\mathrm{i}, \mathrm{t}}$ & 0.1895 & 3.34 & 0.00 \\
$\mathrm{~d} 2 . \mathrm{Hc} \mathrm{i}_{\mathrm{i}, \mathrm{t}}$ & 0.1264 & 2.49 & 0.01 \\
$\mathrm{Fdi}_{\mathrm{i}, \mathrm{t}}$ & -0.0001 & -14.97 & 0.00 \\
Constant & -0.0115 & -2.63 & 0.00 \\
AR $(1)$ & & & 0.00 \\
AR $(2)$ & & & 0.09 \\
SARGAN & & & 0.79 \\
\hline
\end{tabular}

Source:Author

At table 10 interaction effects of the variables on TFP growth are given. T statistics are given in parenthesis. In each model one of the variables is excluded in equation and other variables are put in interaction

Table 2: Interaction effect of EFI, IIT, HC and FDI on TFP Growth: 1980-2014 in Natural Resource Rich Countries

\begin{tabular}{|c|c|c|c|c|c|c|c|c|c|c|c|c|}
\hline & $E f_{i, t}$ & $E f_{i, t}$ & $E f_{i, t}$ & $\mathrm{Iit}_{\mathrm{i}, \mathrm{t}}$ & $\mathrm{Iit}_{\mathrm{i}, \mathrm{t}}$ & $\mathrm{Iit}_{\mathrm{i}, \mathrm{t}}$ & $\mathrm{Fdi}_{\mathrm{i}, \mathrm{t}}$ & $\mathrm{Fdi}_{\mathrm{i}, \mathrm{t}}$ & $\mathrm{Fdi}_{\mathrm{i}, \mathrm{t}}$ & $\mathrm{Hc}_{\mathrm{i}, \mathrm{t}}$ & $\mathrm{Hc}_{\mathrm{i}, \mathrm{t}}$ & $\mathrm{Hc}_{\mathrm{i}, \mathrm{t}}$ \\
\hline Coefficients & $\begin{array}{l}0.36 \\
(3.23)\end{array}$ & $\begin{array}{l}0.46 \\
(5.43)\end{array}$ & $\begin{array}{l}0.31 \\
(2.36)\end{array}$ & $\begin{array}{l}-0.38 \\
(-7.59)\end{array}$ & $\begin{array}{l}-0.60 \\
(-6.01)\end{array}$ & $\begin{array}{l}-0.50 \\
(-5.52)\end{array}$ & $\begin{array}{l}0.00 \\
(3.12)\end{array}$ & $\begin{array}{l}-0.00 \\
(-1.19)\end{array}$ & $\begin{array}{l}0.00 \\
(0.32)\end{array}$ & $\begin{array}{l}0.03 \\
(1.49)\end{array}$ & $\begin{array}{l}0.13 \\
(2.91)\end{array}$ & $\begin{array}{l}0.11 \\
(2.45)\end{array}$ \\
\hline $\mathrm{Iit}_{\mathrm{i}, \mathrm{t}} * \mathrm{Fdi}_{\mathrm{i}, \mathrm{t}}$ & $\begin{array}{l}-0.00 \\
(-0.33)\end{array}$ & & & & & & & & & $\begin{array}{l}0.00 \\
(0.80)\end{array}$ & & \\
\hline \multirow[t]{2}{*}{$\mathrm{Iit}_{\mathrm{i}, \mathrm{t}} * \mathrm{Hc}_{\mathrm{i}, \mathrm{t}}$} & & -0.09 & & & & & -0.08 & & & & & \\
\hline & & $(-3.34)$ & & & & & $(-4.41)$ & & & & & \\
\hline \multirow[t]{2}{*}{$\mathrm{Fdi}_{\mathrm{i}, \mathrm{t}} * \mathrm{Hc}_{\mathrm{i}, \mathrm{t}}$} & & & 0.00 & 0.00 & & & & & & & & \\
\hline & & & $(0.07)$ & (5.15) & & & & & & & & \\
\hline \multirow[t]{2}{*}{$\mathrm{Efi}_{\mathrm{i}, \mathrm{t}} * \mathrm{Fdi}_{\mathrm{i}, \mathrm{t}}$} & & & & & 0.00 & & & & & & -0.00 & \\
\hline & & & & & $(0.68)$ & & & & & & $(-0.43)$ & \\
\hline \multirow[t]{2}{*}{$\mathrm{Efi}_{\mathrm{i}, \mathrm{t}} * \mathrm{Hc}_{\mathrm{i}, \mathrm{t}}$} & & & & & & 0.02 & & 0.03 & & & & \\
\hline & & & & & & (4.79) & & (5.13) & & & & \\
\hline $\mathrm{Efi}_{\mathrm{i}, \mathrm{t}} * \mathrm{Iit}_{\mathrm{i}, \mathrm{t}}$ & & & & & & & & & $\begin{array}{l}-0.05 \\
(-2.64) \\
\end{array}$ & & & $\begin{array}{l}-0.04 \\
(-2.02) \\
\end{array}$ \\
\hline
\end{tabular}


At table 11 interaction effect of the variables on TFP growth are given. T-statistics are given in parenthesis.

Table 3: Interaction effect of EFI, IIT, HC and FDI on TFP Growth: 1980-2014 in OECD Countries

\begin{tabular}{|c|c|c|c|c|c|c|c|c|c|c|c|c|}
\hline & d.Efi $i_{i, t}$ & d. $E f_{i, t}$ & d. $E f_{i, t}$ & $\mathrm{Iit}_{\mathrm{i}, \mathrm{t}}$ & $\mathrm{Iit}_{\mathrm{i}, \mathrm{t}}$ & $\mathrm{Iit}_{\mathrm{i}, \mathrm{t}}$ & $\mathrm{Fdi}_{\mathrm{i}, \mathrm{t}}$ & $\mathrm{Fdi}_{\mathrm{i}, \mathrm{t}}$ & $\mathrm{Fdi}_{\mathrm{i}, \mathrm{t}}$ & d2. $\mathrm{Hc}_{\mathrm{i}, \mathrm{t}}$ & $\mathrm{d} 2 . H c_{i, t}$ & $\mathrm{~d} 2 . \mathrm{Hc}_{\mathrm{i}, \mathrm{t}}$ \\
\hline Coefficients & 0.03 & 0.03 & 0.03 & -0.00 & -0.00 & -0.00 & -0.00 & -0.00 & -0.00 & -0.04 & 0.16 & 0.11 \\
\hline & $(31.39)$ & (13.93) & (16.57) & $(-1.4)$ & $(-10.1)($ & $(-12.5)($ & $(-14.8)($ & $(-13.7)$ & $(-16.4)$ & $(-1.62)$ & (10.35) & (4.84) \\
\hline $\mathrm{Iit}_{\mathrm{i}, \mathrm{t}} * \mathrm{Fdi}_{\mathrm{i}, \mathrm{t}}$ & $\begin{array}{r}-0.00 \\
(-10.39)\end{array}$ & & & & & & & & & $\begin{array}{r}-0.00 \\
(-7.42)\end{array}$ & & \\
\hline $\mathrm{Iit}_{\mathrm{i}, \mathrm{t}} * \mathrm{~d} 2 . \mathrm{Hc}_{\mathrm{i}, \mathrm{t}}$ & & & & & & & & & & & & \\
\hline & & $\begin{array}{r}-0.07 \\
(-1.61)\end{array}$ & & & & & $\begin{array}{l}-0.05 \\
(-1,3)\end{array}$ & & & & & \\
\hline $\mathrm{Fdi}_{\mathrm{i}, \mathrm{t}} * \mathrm{~d} 2 . \mathrm{Hc}_{\mathrm{i}, \mathrm{t}}$ & & & $\begin{array}{r}-0.00 \\
(-7.93)(\end{array}$ & $\begin{array}{r}-0.00 \\
-5.19)\end{array}$ & & & & & & & & \\
\hline d. $E f_{i, t} * F d i_{i, t}$ & & & & & & & & & & & & \\
\hline & & & & & $\begin{array}{r}0.00 \\
(22.83)\end{array}$ & & & & & & $\begin{array}{r}0.00 \\
(15.23)\end{array}$ & \\
\hline $\begin{array}{l}\text { d. } \mathrm{Efi}_{\mathrm{i}, \mathrm{t}} \\
* \mathrm{~d} 2 . \mathrm{Hc}_{\mathrm{i}, \mathrm{t}}\end{array}$ & & & & & & -2.79 & & -2.65 & & & & \\
\hline & & & & & & $(-7.50)$ & & $(-7.32)$ & & & & \\
\hline d. $E f_{i, t} * \operatorname{Iit}_{\mathrm{i}, \mathrm{t}}$ & & & & & & & & & $\begin{array}{r}0.03 \\
(12.19)\end{array}$ & & & $\begin{array}{r}0.03 \\
(11.4) \\
\end{array}$ \\
\hline
\end{tabular}

Table 8 and 9 represent significant relationship between TFP and independent variables in both models except FDI at natural resource rich countries. The coefficients in the model show that; IIT appears to be significantly negative in NRR but positive in OECD countries. EFI and HC have positive sign and statistically significant in both samples. FDI has no statistically significant relationship in NRR countries but negative sign in OECD countries although statistically significant.

Although, FDI is statistically insignificant in NRR countries in table 8 , it has positive effect on TFP growth in case of interaction with $\mathrm{HC}$ in table 10 (Regression Models are represented as $\mathrm{Tfp}_{\mathrm{i}, \mathrm{t}}=0.31 \mathrm{Efi}_{\mathrm{i}, \mathrm{t}}+0.00 \mathrm{Fdi}_{\mathrm{i}, \mathrm{t}} * \mathrm{Hc}_{\mathrm{i}, \mathrm{t}}$ and $\mathrm{Tfp}_{\mathrm{i}, \mathrm{t}}=-0.38 \mathrm{Iit}_{\mathrm{i}, \mathrm{t}}+0.00 \mathrm{Fdi}_{\mathrm{i}, \mathrm{t}} * \mathrm{Hc}_{\mathrm{i}, \mathrm{t}}$ ) In OECD countries, FDI has negative effect on TFP growth in Table 9. Table 11 shows that, FDI has positive effect on economic growth as economic freedom increase in this countries (Regression Model is represented as $\mathrm{Tfp}_{\mathrm{i}, \mathrm{t}}=-0.00 \mathrm{Iit}_{\mathrm{i}, \mathrm{t}}+0.00 \mathrm{~d} . \mathrm{Efi}_{\mathrm{i}, \mathrm{t}} * \mathrm{Fdi}_{\mathrm{i}, \mathrm{t}}$ )

\section{Conclusion}

The effects of Economic Freedom (EFI), Intra-Industry Trade (IIT), Human Capital (HC), Foreign Direct Investment (FDI) and their interaction effect together on Total Factor Productivity Growth (TFP) are analyzed by Panel Data analyses covering 1980-2014 period for 34 OECD countries and 20 natural resource rich countries.

Null hypothesis represents positive relation between TFP growth and independent variables. Due to characteristics of data Instrumental Variables regression and Two Step GMM regression are appropriate methodology. The results show statistically significant relationship between TFP and other variables in both models except FDI in natural resource rich countries.

The interaction effects of Economic Freedom (EFI), Intra-Industry Trade (IIT), Human Capital (HC) and Foreign Direct Investment (FDI) together resulted in different effect on TFP growth. 


\section{References}

Abd-el-Rahman, K. (1991). Firms' competitive and national comparative advantages as joint determinants of trade composition. Review of World Economics, 127(1), 83-97

Acar, M. (2010). Serbest ticaret, ekonomik özgürlükler ve refah. Ahmet Yesevi Üniversitesi, Bilig Türk Dünyası Sosyal Bilimler Dergisi, (53), 56.

Acemoglu, D., Aghion, P., and Zilibotti, F. (2006). Distance to frontier, selection, and economic growth. Journal of the European Economic association, 4(1), 37-74.

Aghion, P., A and Howitt P. (1988), Growth and Cycles through Creative Destruction. Unpublished, University of Western Ontario.

Aghion, P., Meghir, C., and Vandenbussche, J. (2005). Growth, Distance to Frontier and Composition of Human Capital (No. 4860). CEPR Discussion Papers.

Akkaya, M. (2019). The Relationship Between Direct Foreign Capital Investment, Economic Freedom And Economic Growth In Emerging Markets. Selçuk Üniversitesi Sosyal Bilimler Meslek Yüksekokulu Dergisi, 22(1), 1-10.

Alfaro, L., Kalemli-Ozcan, S., and Sayek, S. (2009). FDI, productivity and financial development. World Economy, 32(1), 111-135

Anderson, T. W., and Hsiao, C. (1981). Estimation of dynamic models with error components. Journal of the American statistical Association, 76(375), 598-606.

Arellano, M., and Bond, S. (1991). Some tests of specification for panel data: Monte Carlo evidence and an application to employment equations. The review of economic studies, 58(2), 277-297

Arezki, M. R., Kazimov, M. K., and Hamilton, M. K. (2011). Resource windfalls, macroeconomic stability and growth: the role of political institutions. International Monetary Fund.

Asiedu, E. (2013). Foreign direct investment, natural resources and institutions. International Growth Centre

Azman-Saini, W. N. W., Baharumshah, A. Z., and Law, S. H. (2010). Foreign direct investment, economic freedom and economic growth: International evidence. Economic Modelling, 27(5), 1079-1089

Bakkalcı, A. C. (2013). Yeni yeni ticaret teorilerinin makro-ekonomik doğası ve Türk ekonomisi. Yönetim Bilimleri Dergisi, 11(22)

Balassa, B. A. (1979). Intra-industry trade and the integration of developing countries in the world economy.

Balassa, B. (1986). Intra-industry specialisation. European Economic Review, 30(1), 27-42.

Baltabaev, B. (2014). FDI and Total Factor Productivity Growth: New Macro Evidence (No. 27-13). Monash University, Department of Economics.

Baltagi, B. H., and Li, Q. (1995). Testing AR (1) against MA (1) disturbances in an error component model. Journal of Econometrics, 68(1), 133-151

Barro, R. J. (1991). Economic growth in a cross section of countries. The quarterly journal of economics, $106(2)$, 407-443.

Bengoa, M., and Sanchez-Robles, B. (2003). Foreign direct investment, economic freedom and growth: new evidence from Latin America. European journal of political economy, 19(3), 529-545

Benhabib, J., and Spiegel, M. M. (1994). The role of human capital in economic development evidence from aggregate cross-country data. Journal of Monetary economics, 34(2), 143-173.

Bernard, A. B., Jensen, J. B., and Schott, P. K. (2006). Trade costs, firms and productivity. Journal of monetary Economics, 53(5), 917-937 
Blanchard,O.,2003. Macroeconomics, Pearson Education International, ThirdEdition

Bokpin, G. A., Mensah, L., and Asamoah, M. E. (2015). Foreign direct investment and natural resources in Africa. Journal of Economic Studies, 42(4), 608-621

Borensztein, E., De Gregorio, J., and Lee, J. W. (1998). How does foreign direct investment affect economic growth? 1. Journal of international Economics, 45(1), 115-135.

Brander, J. A. (1981). Intra-industry trade in identical commodities. Journal of international Economics, 11(1), 1-14

Breusch, T. S., and Pagan, A. R. (1980). The Lagrange multiplier test and its applications to model specification in econometrics. The Review of Economic Studies, 47(1), 239253.

Cabral, R., and Mollick, A. V. (2011). Intra-industry trade effects on Mexican manufacturing productivity before and after NAFTA. The Journal of International Trade \& Economic Development, 20(1), 87-112

Cagetti, M., and De Nardi, M. (2006). Entrepreneurship, frictions, and wealth. Journal of political Economy, 114(5), 835-870.

Campbell, N., \& Snyder, T. (2012). Economic freedom and economic volatility. Journal of International and Global Economic Studies, 5(2), 60-76.

Caselli, F. (2005). Accounting for cross-country income differences. Handbook of economic growth, 1, 679-741.

Chen, J., and Fleisher, B. M. (1996). Regional income inequality and economic growth in China. Journal of comparative economics, 22(2), 141-164.

De Mello, L. R. (1999). Foreign direct investment-led growth: evidence from time series and panel data. Oxford economic papers, 51(1), 133-151

Falvey, R. E., and Kierzkowski, H. (1987). Product quality, intra-industry trade and (im) perfect competition.

Finger, J. M. (1975). Trade overlap and intra-industry trade. Economic inquiry, 13(4), 581589.

Fleisher, B., Li, H., and Zhao, M. Q. (2010). Human capital, economic growth, and regional inequality in China. Journal of development economics, 92(2), 215-231.

Faúndez, S. (2011). Productivity growth in Latin American manufacturing: what role for international trade intensities?

Görg, H., and Greenaway, D. (2004). Much ado about nothing? Do domestic firms really benefit from foreign direct investment?. The World Bank Research Observer, 19(2), 171-197

Gray, H. P. (1976). Two-way Trade. In A Generalized Theory of International Trade (pp. 172186). Palgrave Macmillan, London

Grubel, H. and Lloyd P.J.(1975). Intra-Industry Trade:The Theory and Measurement of International Trade in Differentiated Products, London: MacMillan Press

Gwartney, J. D., Holcombe, R. G., and Lawson, R. A. (2004). Economic freedom, institutional quality, and cross-country differences in income and growth. Cato J., 24, 205.

Hakura, M. D., and Jaumotte, M. F. (1999). The role of inter-and intraindustry trade in technology diffusion. International Monetary Fund.

Helpman, E. and P. Krugman (1985). Market Structure and Foreign Trade: Incresing Returns, Imperfect Competition, and the International Economy, London: MIT Press.

Heritage Foundation, (2008), 2008 Index of economic freedom. Washington, DC

Herzer, D., and Donaubauer, J. (2018). The long-run effect of foreign direct investment on total factor productivity in developing countries: a panel cointegration analysis. Empirical Economics, 54(2), 309-342. 
Irandoust, J. E. M. (2001). On the causality between foreign direct investment and output: a comparative study. The International Trade Journal, 15(1), 1-26.

Krugman, P. R. (1979). Increasing returns, monopolistic competition, and international trade. Journal of international Economics, 9(4), 469-479.

Lam, Kwok Ying.,2010. Institutions and Economic Development. Phd Thesis,201

Lewrick, U., Mohler, L., and Weder, R. (2014). When firms and industries matter: understanding the sources of productivity growth.

Iimi, A. (2006). Did Botswana escape from the resource curse?

Lluís Carrion-i-Silvestre, J., Del Barrio-Castro, T., and López-Bazo, E. (2005). Breaking the panels: An application to the GDP per capita. The Econometrics Journal, 8(2), 159175.

Loertscher, R., and Wolter, F. (1980). Determinants of intra-industry trade: Among countries and across industries. Review of World Economics, 116(2), 280-293.

Lewrick, U., Mohler, L., and Weder, R. (2014). When firms and industries matter: understanding the sources of productivity growth.

Loesler, I., Mies, V., and Tapia, M. (2015). The Causal Impact of Human Capital on R\&D and Productivity: Evidence from the United States. Pontificia Universidad Católica de Chile-Documento de Trabajo no, 466

Manuelli, R., and Seshadri, A. (2005). Human capital and the wealth of nations. March.

Manuelli Rodolfo, E., and Seshadri, A. (2005). Human Capital and the Wealth of Nations. Mimeo, May.

Maria J. Freire Seren, (2001). Human Capital Accumulation and Economic Growth, Investigaciones Economicas, 25( )3,585-602.

Mehlum, H., Moene, K., and Torvik, R. (2006). Institutions and the resource curse. The economic journal, 116(508), 1-20.

Melitz, M. J. (2008). International trade and heterogeneous firms. The New Palgrave Dictionary of Economics, 2.

Mileva, E. (2007). Using Arellano-Bond dynamic panel GMM estimators in Stata. Economics Department, Fordham University, 1-10

Miller, S. M., and Upadhyay, M. P. (2000). The effects of openness, trade orientation, and human capital on total factor productivity. Journal of development economics, 63(2), 399-423.

Naanwaab, C., and Diarrassouba, M. (2016). Economic freedom, human capital, and foreign direct investment. The Journal of Developing Areas, 50(1), 407-424

Namini, J. E. (2007). Trade, neoclassical growth and heterogeneous firms.

Nelson, R. R., and Phelps, E. S. (1966). Investment in humans, technological diffusion, and economic growth. The American economic review, 56(1/2), 69-75.

Romer, P. M. (1990). Endogenous technological change. Journal of political Economy, 98(5, Part 2), S71-S102.

Pesaran, M. H., Ullah, A., and Yamagata, T. (2008). A bias-adjusted LM test of error crosssection independence. The Econometrics Journal, 11(1), 105-127.

Pesaran, M. H. (2004). General diagnostic tests for cross section dependence in panels.

Poelhekke, S., and van der Ploeg, F. (2013). Do natural resources attract nonresource FDI?. Review of Economics and Statistics, 95(3), 1047-1065

Prescott, E. (1997). Needed: A Theory of Total Factor Productivity Department Staff Report. Federal Reserve Bank of Minneapolis Research. 
Psacharopoulos, G. (1994). Returns to investment in education: A global update. World development, 22(9), 1325-1343.

Rasekhi, S., and Ramezani, M. (2017). The Nexus between Economic Growth and IntraIndustry Trade. International Journal of Business and Development Studies, 9(1), 47 66

Schultz, T. W. (1961). Investment in human capital. The American economic review, 51(1), $1-17$.

Scully, G. W., and Slottje, D. J. (1991). Ranking economic liberty across countries. Public Choice, 69(2), 121-152.

Shahbaz, M., and Lean, H. H. (2012). Does financial development increase energy consumption? The role of industrialization and urbanization in Tunisia, Energy policy, 40, 473-479

Ulusoy, V., and Taş, C. (2017). On the effects of total productivity growth of economic freedom and total resource rents: The case of both natural resource rich and OECD countries. Theoretical and Applied Economics, 22(3 (612), Autumn), 173-192.

Unctad (1999), World Investment Report, UNCTAD, Geneva

Vandenbussche, J., Aghion, P., \& Meghir, C. (2006). Growth, distance to frontier and composition of human capital. Journal of economic growth, 11(2), 97-127.

Ventura, J. (1997). Growth and interdependence. The Quarterly Journal of Economics, 112(1), 57-84.

Verdoorn, P. J. (1960). The intra-bloc trade of Benelux. In Economic consequences of the size of nations (pp. 291-329). Palgrave Macmillan, London.

Wang, M., and Wong, M. S. (2009). Foreign direct investment and economic growth: The growth accounting perspective. Economic Inquiry, 47(4), 701-710.

Wang, P., and Xie, H. D. (2008). Hetergeneous Sectors, Trade, and Growth.

Woo J (2009) Productivity growth and technological diffusion through foreign direct investment. Econ Inq, 47(2),226-248

\section{Appendix A}

Table 4: List of Natural Resource Rich Countries

\begin{tabular}{llll}
\hline NRR COUNTRY & Code & NRR COUNTRY & Code \\
\hline Australia & AUS & Kuwait & KWT \\
Bolivia & BOL & Malaysia & MYS \\
Brazil & BRA & Mexico & MEX \\
Canada & CAN & Norway & NOR \\
Chile & CHL & Peru & PER \\
China & CHN & Russian Federation & RUS \\
Ecuador & ECU & South Africa & ZAF \\
India & IND & Trinidad and Tobago & TTO \\
Indonesia & IDN & United States & USA \\
Kazakhstan & KAZ & Venezuela, RB & VEN \\
\hline Source: Author & & &
\end{tabular}

Table 5. List of OECD Countries

\begin{tabular}{lllll}
\hline OECD Country & Code OECD Country & Code OECD Country & Code OECD Country & Code \\
\hline Australia & AUS France & FRA Korea, Rep. & KOR Slovenia & SVN \\
Austria & AUT Germany & DEU Luxembourg & LUX Spain & ESP \\
Belgium & BEL Greece & GRC Mexico & MEX Sweden & SWE \\
Canada & CAN Hungary & HUN Netherlands & NLD Switzerland & CHE
\end{tabular}




\begin{tabular}{|c|c|c|c|c|c|}
\hline Chile & CHL Iceland & ISL & New Zealand & NZL Turkey & TUR \\
\hline Czech Republic & CZE Ireland & IRL & Norway & NOR United Kingdom & GBR \\
\hline Denmark & DNK Israel & ISR & Poland & POL United States & USA \\
\hline Estonia & EST Italy & ITA & Portugal & PRT & \\
\hline Finland & FIN Japan & JPN & Slovak Republic & SVK & \\
\hline
\end{tabular}

Source:Author

\section{Appendix B}

\section{Total factor productivity}

Robert Solow (1956) is the first in literature explaining total productivity by the Cobb-Douglas (1928)'s production function in which there is single good with two factors.

$Y=A(t) F[K(t), L(t)]=A K^{\alpha}(E H c)^{1-\alpha}$

$\mathrm{Y}=$ Total production,

$\mathrm{L}=$ Labor input,

$\mathrm{K}=$ Capital input,

$\mathrm{A}=$ Total factor productivity

$\mathrm{E}=$ Number of Workers in Economy

$\mathrm{Hc}=$ Average Human Capital

$\alpha=$ Output elasticity of capital

$1-\alpha=$ Output elasticity of labor

A second order approximation to the production function $\mathrm{f}$ is the Tornqvist quantity index of factor inputs $Q_{i j}^{T}$, which can be used for comparing productivity between countries $\mathrm{i}$ and $\mathrm{j}$ at a given time.

$\operatorname{In} Q_{i j}^{T}=\frac{1}{2}\left(\alpha_{i}+\alpha_{j}\right) \operatorname{In} \frac{K_{i}}{K_{j}}+\left\lfloor 1-\frac{1}{2}\left(\alpha_{i}+\alpha_{j}\right)\right\rfloor \operatorname{In} \frac{L_{i}}{L_{j}}$

The measure of total factor productivity (TFP) that is comparable across countries is then defined as:

$C T F P_{i j}={ }^{\frac{\operatorname{CGDP} P_{i}^{\partial}}{C G D P_{j}^{\partial}}} / Q_{i j}^{T}$

Where $C G D P_{i}^{\partial}$ is the real GDP measure in PWT8.0 that accounts for differences in the terms of trade and is thus a proper measure of the productive capacity of economy.

Analogously, we can compare inputs between $t-1$ and $t$ for a given country

as:

$\operatorname{In} Q_{t ; t-1}^{T}=\frac{1}{2}\left(\alpha_{t}+\alpha_{t-1}\right) \operatorname{In} \frac{K_{t}}{K_{t-1}}+\left\lfloor 1-\frac{1}{2}\left(\alpha_{t}+\alpha_{t-1}\right)\right\rfloor \operatorname{In} \frac{L_{t}}{L_{t-1}}$

Growth of productivity is then given by:

$R T F P_{t ; t-1}^{N A}={ }^{\frac{R G D P_{t}^{N A}}{R G D P_{t-1}^{N A}}} / Q_{t ; t-1}^{T}$ 
which uses $R G D P_{t}^{N A}$ real GDP at constant national prices from PWT8.0, which is the best measure of economic growth.

\section{Human Capital}

The human capital index available since PWT version 8.0 makes empirical researches with a focus on human capital and cross-country comparisons more viable5. It is calculated based on average years of education and an estimated rate of return to education from the Mincer6 equation. That is,

$H c=e^{\emptyset(s)}$

$\emptyset_{s}=\left\{\begin{array}{c}0.134 s \quad \text { if } s \leq 4 \\ 0.134 * 4+0.101(s-4) \text { if } 4<s \leq 8 \\ 0.134 * 4+0.101 * 4+0.068(s-8) \text { if } s>8\end{array}\right\}$

because the early years of education are evidenced to have a higher return than the later years in some studies7.In this equation s means average years of schooling.

\section{Intra Industry Trade}

The Balassa index, Grubel-Lloyd index, The Aquino formula, The Bergstrand method etc. (Balassa, 1966; Grubel, Lloyd, 1975; Aquino, 1978; Bergstrand, 1990) are main measurement tools.

Export and import data's of ten main products group are gathered to get the The Grubel-Lloyd Index. Weighted average value of export/import values are used to get one data for one year of each country. The formula to get the Index is as follows. In this equation $i$ reperesents sector.

$G L_{i}=1-\left[\frac{\mid \text { export }_{i}-\text { import }_{i} \mid}{\text { export }_{i}+\text { import }_{i}}\right]$

If the country only imports or only exports goods or services within the same sector, such that there is no intra-industry trade, the second term on the right-hand side of equation is equal to one, such that the whole expression reduces to zero. Similarly, if the export value is exactly equal to the import value the second term on the right-hand side of equation is equal to zero, such that the whole expression reduces to one. The Grubel-Lloyd index therefore varies between zero (indicating all trade is inter-industry) and 100 (indicating all trade is intraindustry). The closer the value of the index to 100 the greater is the degree of intra-industry trade. A high value of this indicating it participates actively in global value chains and benefits from technology transfers which may increases its productivity. In contrast, if a country exports and imports goods that belong to different industries, its trade is of an inter-industry type, and the value of the index approaches 0 . In this case, its trade relations are more likely to be of an arm's length type, with fewer possibilities of technology transfer.

The indices reported in this chapter have been computed according to each pair of trading partners and for each two digit SITC (the standard international trade classification) is used, revision 2 product class.

Product class are as follows:

\footnotetext{
${ }^{5}$ Fang\&Chang, 2016

${ }^{6}$ Psacharopoulos, 1994

${ }^{7}$ Caselli, 2005
} 
Animal and vegetable oils, fats and waxes

- Beverages and tobacco

- Chemicals and related products, n.e.s.

- Commodities and transactions not elsewhere classify.

- Crude materials, inedible, except fuels

- Food and live animals

- Machinery and transport equipment

- Manufactured goods classified chiefly by material

- Mineral fuels, lubricants and related materials

- Miscellaneous manufactured articles

\section{Appendix C}

Government size : Bigger government may indicate a lack of competition in public and create inefficiencies by allocating resources toward rent-seeking activities instead of production.

Legal system and property rights: A lack of property rights protections negatively affects individual and business investment decisions, causes inefficiencies, and therefore deters economic growth.

Access to sound money: Unsound monetary policies distort relative prices and create uncertain environments, making it difficult for entrepreneurs to plan wisely and less eager to innovate, leading to lower productivity and so hinder economic growth.

International trade and trade policies: The trade literature suggests that protective trade policies and trade restrictions are associated with considerable rents and rent-seeking activities. The tendency of governments to allocate export quotas to some "registered exporters" captures a greater share of rents, leading to imperfectly competitive markets and raising rent-seeking activities.

Regulation of business, labor, and credit markets: Regulation can be both a help and a hindrance for economic growth in resource-rich countries. On the one hand, setting efficient business, labor, and credit regulations can reduce rent-seeking behavior and corruption and consequently mitigate the effects of the resource curse. On the other hand, the windfall income from natural resources allows governments in resource-rich economies to intervene in various markets and private-sector activities

Government size index (GVZ) ranges from 0-10. Countries with a larger proportion of government expenditures, with larger transfer sectors, when government investment exceed $50 \%$ of total investment, with the higher marginal tax rates gets 0 rates.

Legal System and Property Rights index (LEG) ranges from 0-10. Countries with no judicial independence, inefficient legal framework for private businesses, no protection of property rights, high militaries involvement in politics and no integrity of legal system gets 0 rates.

Access to sound money index (SMN) ranges from 0-10. Countries, where the money supply growth rate greatly exceeds real output growth rate, where the annual standard deviation of the 
inflation rate is approximately $25 \%$, where annual inflation rate is over $50 \%$ and where foreign currency bank accounts were restricted both domestically and abroad gets 0 rates.

Freedom to trade internationally index (FRT) ranges from 0-10. Countries with more than $\% 15$ taxes on international trade, mean tariff rates is nearly $\% 50$, the standard deviation of tariff rates increases toward $25 \%$, longer import or export procedures, the percentage difference between official exchange rates and black-market rates is over 50\%, highly restrictive regulations for international capital flow, highly capital control gets 0 rates.

Regulation index (REG) ranges from 0-10. It includes credit market, Labor market and Business regulations. Countries where $10 \%$ or less of private deposits held in privately owned banks, where greater government borrowing occurs, where lending and deposit rates are fixed by the government, where fixed-term working contracts are used for any kinds of task, where hiring and firing of workers is hindered by regulation, where wages are set by a centralized bargaining process, where conscription period is over 18 months, to start a new business takes longer times or more costly, long time and high monetary cost to obtain licence to construct warehouse gets 0 rates. 